\title{
Evidence of platelet activation in multiple sclerosis
} William A Sheremata ${ }^{1}$, Wenche Jy², Lawrence L Horstman², Yeon S Ahn², J
Steven Alexander ${ }^{3}$ and Alireza Minagar*4

Address: ${ }^{1}$ Multiple Sclerosis Center and Department of Neurology Miller School of Medicine, University of Miami, Miami, Florida, USA, ${ }^{2}$ Wallace Coulter Platelet Laboratory, Division of Hematology and Oncology, Department of Medicine, Miller School of Medicine, University of Miami, Miami, Florida, USA, ${ }^{3}$ Department of Cellular and Molecular Physiology, Louisiana State University Health Science Campus, Shreveport, Louisiana, USA and ${ }^{4}$ Department of Neurology, Louisiana State University Health Science Campus, Shreveport, Louisiana, USA

Email: William A Sheremata - sheremaw@bellsouth.net; Wenche Jy - wenche_jy@yahoo.com;

Lawrence L Horstman - lhorstman@med.miami.edu; Yeon S Ahn - yahn@med.miami.edu; J Steven Alexander - jalexa@lsuhsc.edu; Alireza Minagar* - aminag@Isuhsc.edu

* Corresponding author

Published: 27 June 2008

Journal of Neuroinflammation 2008, 5:27 doi:10.1186/1742-2094-5-27
Received: 3 March 2008

Accepted: 27 June 2008

This article is available from: http://www.jneuroinflammation.com/content/5/I/27

(c) 2008 Sheremata et al; licensee BioMed Central Ltd.

This is an Open Access article distributed under the terms of the Creative Commons Attribution License (http://creativecommons.org/licenses/by/2.0), which permits unrestricted use, distribution, and reproduction in any medium, provided the original work is properly cited.

\begin{abstract}
Objective: A fatality in one multiple sclerosis (MS) patient due to acute idiopathic thrombocytopenic purpura (ITP) and a near fatality in another stimulated our interest in platelet function abnormalities in MS. Previously, we presented evidence of platelet activation in a small cohort of treatment-naive MS patients.

Methods: In this report, 92 normal controls and 33 stable, untreated MS patients were studied. Platelet counts, measures of platelet activation [plasma platelet microparticles (PMP), P-selectin expression (CD62p), circulating platelet microaggragtes (PAg)], as well as platelet-associated lgG/ IgM, were carried out. In addition, plasma protein $S$ activity was measured.

Results: Compared to controls, PMP were significantly elevated in MS $(p<0.001)$ and CD62p expression was also markedly elevated $(p<0.00 \mathrm{I})$. Both are markers of platelet activation. Plateletassociated IgM, but not $\lg G$, was marginally elevated in MS $(p=0.01)$. Protein $S$ in MS patients did not differ significantly from normal values.

Conclusion: Platelets are significantly activated in MS patients. The mechanisms underlying this activation and its significance to MS are unknown. Additional study of platelet activation and function in MS patients is warranted.
\end{abstract}

\section{Background}

The fatal outcome in one of two multiple sclerosis (MS) patients with idiopathic thrombocytopenic purpura (ITP) prompted our interest in platelet activity and function in the context of MS. Although Putnam investigated a possible role of venule thrombosis as a factor in central nervous system (CNS) demyelination in 1935 [1], a role for platelets in CNS demyelination was not further considered until a series of papers in the 1960s, such as that of Wright et al. [2] For example, Nathanson and Savitsky [3] employed a measure of platelet adhesiveness in 132 subjects, 60 of whom had MS. The investigators reported increased platelet adhesiveness in both MS and GuillainBarre correlating with disease activity. Although other investigations confirmed their findings, they contributed little additional information. More recently, a central role 
for platelets in inflammation has emerged, as reviewed $[4,5]$.

Our observation of platelet abnormalities in MS [6] and subsequent observation of thrombosis in cutaneous venules and capillaries adjacent to subcutaneous ulcers complicating subcutaneous injections of interferonbeta1b [7] heightened our interest in a possible role of platelet dysfunction in MS. To investigate the basis of these observations, we have applied the flow cytometric analysis of platelet-derived microparticles (PMP) and CD62p expression, as well as other more conventional assays. For this study, we employed consecutively recruited patients and measured, in addition to routine tests such as platelet counts, the expression of platelet activation marker P-selectin (CD62p), platelet microparticles (PMP) in plasma, platelet micro-aggregates (PAg), protein $S$ activity, and platelet-associated immunoglobulins IgG and IgM, as described following.

\section{Methods}

\section{Patient population}

Thirty-three treatment-naïve, clinically stable relapsingremitting MS patients and 92 normal control subjects were recruited. The study protocol was approved by the IRB office of University of Miami and signed informed consents were obtained.

\section{Blood sampling}

A $4.5 \mathrm{~mL}$ blood sample was drawn into Vacutainer ${ }^{\circledR}$ tubes containing citrate, using a 21-gauge butterfly needle following light application of a tourniquet. After blood flow was established, the tourniquet was promptly removed to minimize artifactual platelet activation. The first tube drawn was not used for platelet studies to avoid platelet activation from thromboplastin released by the puncture wound. Samples were prepared for flow cytometry not more than 2 hours after phlebotomy. Although drawing into Vacutainers induces slight platelet activation compared to the syringe method, they were required by the phlebotomy clinic, and normal controls were drawn in the same way.

\section{Platelet counts and protein S assay}

Platelet counts and plasma protein S activities were carried out by the clinical pathology laboratories, University of Miami. Normal ranges of values were used for reference.

\section{Platelet microparticle (PMP) assay}

The method as described by Jy et al. $[8,9]$ was employed with minor modifications [10,11]. Briefly, platelet-rich plasma (PRP) was prepared by centrifuging whole blood $10 \mathrm{~min}$. at $160 \times \mathrm{g}$. Platelet-poor plasma (PPP) was then prepared by centrifuging PRP for $6 \mathrm{~min}$. at $2000 \times \mathrm{g}$. Five $\mu \mathrm{L}$ of fluorescein isothiocyanate (FITC)-conjugated antiCD4 1 was added to $20 \mu \mathrm{L}$ of PPP, and after 20 min., $25 \mu \mathrm{L}$ of $4 \%$ PFA fixative also added. After $20 \mathrm{~min}$. fixation, 2.0 $\mathrm{mL}$ of PBS was added and PMP were measured by flow cytometry with the neutral density filter removed. Events were detected and counted by triggering on the fluorescent signal. Results are expressed as $\mathrm{PMP} \times 10^{7} / \mu \mathrm{L}$ plasma. Particle counts measured in 1-minute runs were converted to concentrations in plasma based on the dilution factor and rate of flow through the cytometer, as detailed [12].

\section{Platelet aggregates (PAg)}

Circulating PAg were measured by flow cytometry, as described $[13,14]$. This assay reflects the tendency of activated platelets to form micro-aggregates in circulation.

\section{Platelet activation marker P-selectin (CD62p)}

Platelet activation marker P-selectin (CD62p) was measured by flow cytometry using phycoerythrin (PE)-labeled anti-CD62p together with platelet marker, anti-CD41, as described $[15,16]$. Briefly, to $5 \mu \mathrm{L}$ of citrated whole blood was added $100 \mu \mathrm{L}$ PBS, and then $5 \mu \mathrm{L}$ of each mAb. After $10 \mathrm{~min}, 160 \mu \mathrm{L}$ of $4 \%$ PFA in PBS was added. Following $10 \mathrm{~min}$. fixation, $1.0 \mu \mathrm{L}$ of PBS was added, and after 2 hours hemolysis the sample was ready for cytometry. All samples were counted for 1 minute.

\section{Platelet-associated IgG, IgM}

Platelet associated immunoglobulin was measured as described [17], except that the $\mathrm{F}(\mathrm{ab})_{2}$ fragment of goat anti-human IgG and IgM was employed to reduce nonspecific Fc-dependent binding, thus increasing accuracy of the measurement. In our method, fresh platelets are isolated in the presence of $2 \mathrm{mM}$ EGTA and $2 \mu \mathrm{M}$ prostaglan$\operatorname{din} \mathrm{E}_{1}$, preventing activation and emergence of internal IgG and IgM on the platelet surface, thereby avoiding objections sometimes raised regarding measurement of platelet-associated IgG and IgM.

\section{Results \\ Platelet counts}

Mean platelet counts for the $\mathrm{n}=33$ patients were within the normal range $\left(261 \pm 95 \times 10^{3} / \mu \mathrm{L}, \pm\right.$ S.D. $)$, as compared with the reference value for the normal controls $\left(259 \pm 90 \times 10^{3} / \mu \mathrm{L}\right)$ studied concomitantly; $\mathrm{p}=$ NS (Figure $1 \mathrm{~A})$. However, $7 \mathrm{MS}$ patients had platelets counts $/ \mu \mathrm{L}$ $<200,000$ and 3 had counts $\leq 150,000(76,000,100,000$, $150,000)$, consistent with our experience that mild thrombocytopenia is not uncommon in MS patients.

\section{Platelet activation marker CD62p}

The mean fluorescence intensity of CD62p, a marker of platelet activation, was also elevated in MS as compared to controls: mean values \pm SD were $4.4 \pm 3.6$ for the MS and $2.5 \pm 1.3$ for the controls; $\mathrm{p}<0.001$ (Figure 1B). 

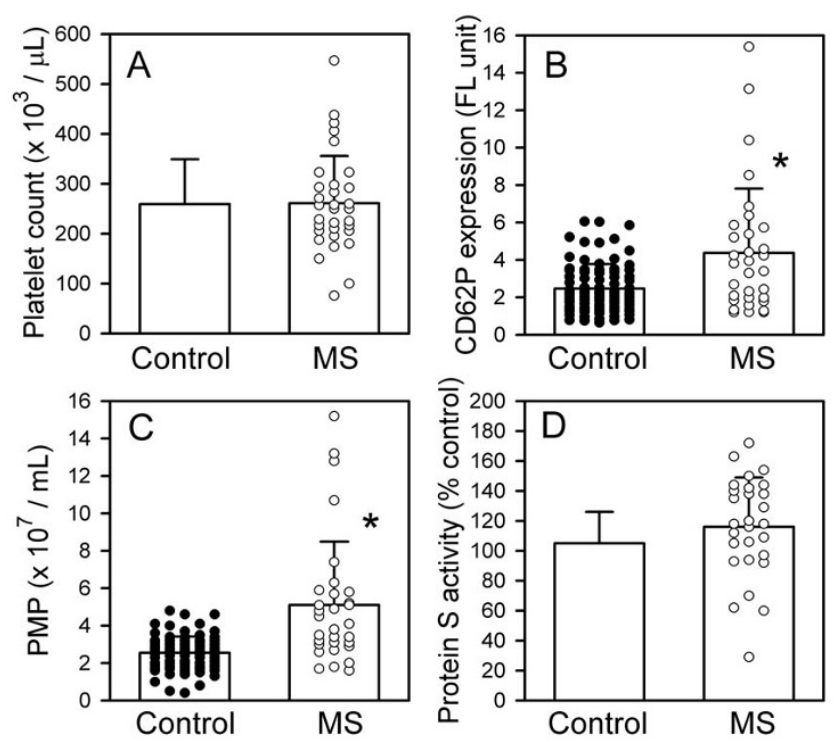

Figure I

Comparison of platelet count, platelet activation marker CD62P expression, PMP, and protein S between controls and MS patients. (A) Mean platelet counts did not differ between the MS and control groups.

(B) Elevation of platelet activation marker CD62p in the MS group was highly significant, $* \mathrm{P}<0.00 \mathrm{I}$. Not shown or included in the analysis was one extremely high value (60.6), possibly a technical error. (C) PMP counts in the MS patients were significantly higher than controls, ${ }^{*} p<0.00$ I. Not shown or included in the analysis was one very high outlying value (25.2). (D) Protein S activity (\% control) did not differ significantly between MS and controls. All values are expressed as mean \pm SD. The institutional control values (mean \pm SD) of platelet count and protein S activity were obtained from the laboratory of University of Miami Hospital and Clinics, and are not shown as individual dots because the numbers are too large.

\section{Platelet microparticles (PMP)}

In the MS group, PMP were elevated by approximately a two-fold margin compared with the controls (Figure 1C). The mean value for the MS patients was $5.1 \pm 3.4\left(\times 10^{7} /\right.$ $\mathrm{mL}, \pm \mathrm{SD})$, compared to $2.5 \pm 0.9$ for controls; $\mathrm{p}<0.001$. These PMP are released into the plasma in the process of platelet activation and are known to exhibit procoagulant activity. This is accomplished by supplying a suitable phospholipid surface for assembly of the factor X-ase and factor II-ase (prothrombinase) complexes, known as platelet factor 3 (PF3) activity [18], and by carrying tissue factor (TF) $[19,20]$.

\section{Platelet micro-aggregates (PAg)}

Circulating platelet micro-aggregates, an additional marker of platelet activation, was also elevated in the MS group, relative to controls, $\mathrm{p}=0.01$, to a degree similar to the CD62p (data not shown).

\section{Protein S activity}

No significant difference was found between the MS and control groups in this measure (Figure 1D). Values were, \pm SD, $105 \pm 21 \%$ for controls and $116 \pm 33 \%$ for MS patients.

\section{Platelet surface-associated IgG, IgM}

Immunoglobulin IgM associated with platelets was significantly elevated in the MS group $(7.8 \pm 6.5$ percent cells positive) as compared to controls $(3.4 \pm 1.3), \mathrm{p}<0.01$ (Figure $2 \mathrm{~B})$. However, IgG was not increased $(3.4 \pm 2.7$ in MS vs. $2.7 \pm 1.3$ in controls) (Figure $2 \mathrm{~A}$ ). This IgM may represent immune complex formation, autoantibody, or it could reflect chronic platelet activation. Chronic platelet activation has been reported to cause externalization of immunoglobulins normally found within platelets. Surface expression of IgM may sensitize the platelet for destruction by complement [10], or alternatively, by the reticuloendothelial system.

\section{Discussion}

By all three measures (PMP, PAg, CD62p), we have documented the presence of platelet activation in MS patients. Increased PMP and increased CD62p expression are accepted markers of platelet activation $[15,21]$. Our observations strongly support the conclusion that platelets are chronically activated in MS, and support results in the earlier literature [2].

Platelet activation may be an epiphenomenon consequent to the disease process in MS, possibly secondary to endothelial injury. Indeed, we have reported elevated plasma endothelial microparticles (EMP) in MS, positive for platelet endothelial cell adhesion molecule-1 (CD31/ PECAM-1) [22] and suggested that this increase in EMP may reflect the interaction of activated T-cells with endothelium. It is also possible that interaction of released PMP with underlying endothelium contributes to the endothelial abnormalities involved in the pathophysiology of MS. Binding of P-selectin on PMPs to Pselectin glycoprotein ligand-1 (PSGL-1) and PECAM-1 on lymphocytes is known to induce or increase the expression of integrins such as integrin $\alpha 4 \beta 1$ (VLA- 4 ), and thus facilitate lymphocyte binding to endothelium [23]. However; the in vivo role of CD62p+ PMP and CD31+ EMP and their interactions in MS remains unknown. It is known that PMP can transport a variety of bioactive agents including platelet activating factor (PAF), amyloid precursor protein, complement factors, and other molecules $[24,25]$, all of which could contribute to the disease process in some manner. 

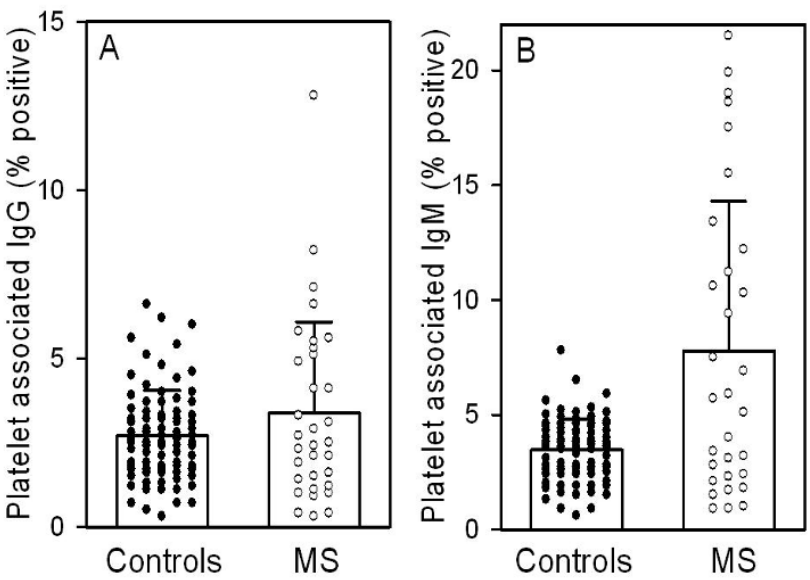

Figure 2

Comparison of platelet-associated IgG and IgM between controls and MS patients. Results are expressed as percentage of platelets positive for the indicated immunoglobulin, where positive is defined as >3SD above the mean for normal subjects in this laboratory by the procedure referenced in the methods section. (A) Results for platelet-associated IgG showed no significant difference between the MS group and controls. Value were, \pm SD: $2.7 \pm$ I. 3 for controls vs. $3.4 \pm 2.7$. (B) In contrast, mean platelet associated $\lg M$ was significantly higher in the MS group, ${ }_{p}<$ $0.0 \mathrm{I}$. Values were, \pm SD: $3.4 \pm \mathrm{I} .3$ for controls vs. $7.8 \pm 6.5$ for MS. Not shown or included in analysis were 2 very high outlying values $(55.9,65.9)$.

Although study of the role of cell-derived microparticles in disease processes is still in its infancy, it is clear that PMP are involved in angiogenesis $[26,27]$ and in certain malignant processes $[28,29]$. In light of these developments, it is reasonable to postulate that PMP may play an active role in the pathogenesis of MS. Several chemokines have been detected on platelets [30] and some are carried by PMP $[31,32]$. The chemokine receptor CXCR4 can be transferred by PMP from cell to cell [33]. Leukocyte activation by PMP has been also reported [34], illustrating another potential link between PMP and the inflammatory disease process.

It remains unclear how platelet activation and the release of PMP pertain to our clinical observation of 2 cases of ITP associated with MS at our center. This finding, in accord with the earlier literature [2], suggests the presence of a procoagulant state in MS, and elements of the coagulation system such as fibrin and tissue factor (TF) are found in MS lesions [35]. However, review of the available literature has identified additional MS patients with ITP complicating their illness. Granier et al in 2001 reported a 40 year old French patient with well-documented MS who had a transient thrombocytopenia [36]. Four additional cases have been identified recently in Spain [37]. However, two earlier cases [1997] with Hodgkin's and thrombocytopenia cannot be accepted as ITP [38]. Recent epidemiological studies in Maryland [39] and in Nova Scotia, Canada [40] have brought to light additional cases. Segal et al. identified 4 such cases in children [39] and Kirby et al. have identified 22 MS patients with "immune thrombocytopenia" [40]. Segal's report reflects a 25-fold higher incidence of ITP in MS in the Maryland study and, although details from the Canadian study are not available, an even higher coincidence may occur there. Although PMPs were thought to possess solely procoagulant properties, it appears that some PMP phenotypes may exert predominantly anticoagulant functions by modulating the protein $\mathrm{C} / \mathrm{S}$ system [41].

Platelet associated IgM was increased in the MS group (p $<0.01$ ) but platelet associated IgG was not. Our finding of elevated platelet-associated IgM and platelet activation may reflect the presence low levels of serum anti-phospholipid antibodies in MS. This finding is consistent with reports of predominately IgM anti-phospholipid antibodies in MS. Sugiyama et al found 14 of 32 patients positive for IgM anti-phospholipid antibody but only 3 of 32 positive for IgG [42]. Using another method, we have found anti-phospholipid antibodies exclusively of IgM class in MS [43]. Patients with the anti-phospholipid syndrome are prone to recurrent stroke, thrombocytopenia, and neurological manifestations resembling those of MS are possible [44].

As the figures show, not all MS patients show elevated platelet activation or platelet-associated IgM. Since this study was not longitudinal, it is not known if the patients with elevated values represent a subset of MS patients, or if most MS patients have occasional or episodic elevations, possibly preceding exacerbations.

The classic neuropathology of MS consists of the perivenular plaque surrounding venular endothelial cells with infiltrating lymphocytes and macrophages [45]. The interactions of these cellular elements and resulting myelin and axonal damage are complex and incompletely understood. Our findings collectively suggest a complex interplay of platelets with endothelial and other cells in the pathogenesis of the MS plaque. The interaction of CD62p, PMP, macrophages, anti-phospholipid antibodies, and the CNS venular endothelium requires further study.

\section{Conclusion}

Findings of this study demonstrate that platelets are significantly activated in MS patients. However, their role in pathogenesis of MS remains unknown. Further longitudinal studies of larger cohorts of MS patients are required to validate the significance of the present study and demon- 
strate the role of platelet activation in neuro-pathogenesis of MS.

\section{Abbreviations}

MS: Multiple sclerosis; ITP: idiopathic thrombocytopenic purpura; PMP: plasma platelet microparticles; CD62p: Pselectin expression; CNS: central nervous system; PAg: platelet micro-aggregates; FITC: fluorescein isothiocyanate; CD62p: P-selectin; TF: tissue factor; PAF: platelet activating factor; PF3: platelet factor 3; CD31/PECAM-1: platelet endothelial cell adhesion molecule-1; PSGL-1: Pselectin glycoprotein ligand-1; PAF: platelet activating factor; PRP: platelet-rich plasma; PPP: platelet-poor plasma.

\section{Competing interests}

The authors declare that they have no competing interests.

\section{Authors' contributions}

WAS, WH, YSA and AM designed the clinical research protocol, provided expertise for laboratory measurement of platelet activity markers.

WJ and LLH contributed to the manuscript by collecting laboratory data, providing expertise for analysis of the obtained laboratory data, and doing biostatistical analysis and generating figures.

JSA contributed by preparing the manuscript and providing expertise in interpreting the obtained data on platelet adhesion molecules.

\section{References}

I. Putnam TJ: Studies in multiple sclerosis (iv) 'encephalitis' and sclerotic plaques produced by venular obstruction. Arch Neurol Neurosurg Psychiat 1935, 33:929-940.

2. Wright HP, Thompson RHS, Zilkha KJ: Platelet adhesiveness in multiple sclerosis. Lancet 1965, 2: I I09-1 I I0.

3. Nathanson M, Savistsky JP: Platelet adhesive index studies in multiple sclerosis and other neurologic disorders. Bull $N Y$ Acad Med 1952, 28(7):462-468.

4. McGregor JL: The role of human platelet membrane receptors in inflammation [Ch 4]. In: Joseph M, ed. Immunopharmacology of Platelets. London/New York: Academic Press; 1995:66-82.

5. Weyrich AS, Lindemann S, Zimmerman CA: The evolving role of platelets in inflammation. J Thromb Haemost 2003, I: I897-I 905.

6. Sheremata WA, Fineberg M, Ahn YS: Association of immune thrombocytopenia and abnormal platelet functions with multiple sclerosis (Abstract). Brain Pathol 1993, 3:293.

7. Elgart GW, Sheremata W, Ahn YS: Cutaneous reactions to recombinant human interferon beta-I b: the clinical and histologic spectrum. J Am Acad Dermatol 1997, 37:553-558.

8. Jy W, Horstman LL, Arce M, Ahn YS: Clinical significance of platelet microparticles in autoimmune thrombocytopenias. J Lab Clin Med 1992, I 1 9:334-345.

9. Lee YJ, Horstman LL, Janania J, Reyes Y, Kelley RE, Ahn YS: Elevated platelet microparticles in transient ischemic attacks, lacunar infarcts, and multiinfarct dementias. Thromb Res 1993, 72:295-304.

10. Horstman LL, Jy W, Schultz DR, Mao WW, Ahn YS: Complement mediated fragmentation and lysis of opsonized platelets: Gender differences in sensitivity. J Lab Clin Med 1994, | 23:515-525.
II. Horstman LL, Valle-Riestra BJ, Jy W, Wang F, Mao W, Ahn YS: Desmopressin [DDAVP] acts on platelets to generate platelet microparticles and enhanced procoagulant activity. Thromb Res 1995, 79:163-174.

12. Jimenez J, Jy W, Mauro L, Horstman L, Ahn Y: Elevated endothelial microparticles in thrombotic thrombocytopenic purpura (TTP): Findings from brain and renal microvascular cell culture and patients with active disease. Br J Haematol 200I, I I 2:8I-90.

13. Ahn YS, Jy W, Kolodny L, Horstman LL, Mao WW, Valant PA, Duncan RC: Activated platelet aggregates in thrombotic thrombocytopenic purpura: decrease with plasma infusions and normalization in remission. BrJ Haematol 1996, 95:408-4I5.

14. Jy W, Horstman LL, Park H, Mao W, Valant P, Ahn YS: Platelet aggregates as markers of platelet activation: Characterization of flow cytometric method suitable for clinical applications. Am J Hematol 1998, 57:33-42.

15. Jy W, Mao WW, Horstman LL, Valant PA, Ahn YS: A flow cytometric assay of platelet activation marker P-selectin (CD62p) distinguishes heparin-induced thrombocytopenia (HIT) from HIT-with-thrombosis (HITT). Thromb Haemost 1999, 82: $1255-1259$.

16. Ozner MD, Ahn YS, Horstman LL, Wenche Jy, Kolodny L, Myerberg RJ: Chronic platelet activation and acute coronary syndromes in 13 middle-aged patients. Clin Appl Thromb Hemost 1997, 3:46-53.

17. Ahn YS, Rocha R, Mylvaganam R, Duncan RC, Harrington WJ: Longterm danazol therapy in ITP: unmaintained remissions and age dependent response in women. Ann lnt Med 1989, I I I :723-729.

18. Jy W, Horstman LL, Wang F, Duncan R, Ahn YS: Platelet factor 3 in plasma fractions: Its relation to microparticle size and thromboses. Thromb Res 1995, 80:47I-482.

19. Siddiqui FA, Desai H, Amirkhosravi A, Amaya M, Francis JL: The presence and release of tissue factor from human platelets. Platelets 2002, 13:247-253.

20. Scholz T, Temmler U, Krause S, Heptinstall S, Losche W: Transfer of tissue factor from platelets to monocytes: role of plateletderived microvesicles and CD62P. Thromb Haemost 2002, 88: 1033-1038.

21. Ahnadi CE, Sabrinah Chapman E, Lepine M, Okrongly D, Pujol-Moix $\mathrm{N}$, Hemandez A, Boughrassa F, Grant AM: Assessment of platelet activation in several different anticoagulants by the Advia 120 Hematology System, fluorescence flow cytometry, and electron microscopy. Thromb Haemost 2003, 90:940-948.

22. Minagar A, Jy W, Jimenez JJ, Sheremata WA, Mauro LM, Mao WW, Horstman LL, Ahn YS: Elevated plasma endothelial microparticles in multiple sclerosis. Neurology 200।, 56:13/9-1324.

23. von Andrian UH, MacKay CR: T-cell function and migration: Two sides of the same coin. N Engl J Med 2000, 343:1020-1034.

24. Horstman LL, Minagar A, Jy W, Bidot CJ, Jimenez JJ, Alexander JS, Ahn YS: Cell-derived microparticles and exosomes in neuroinflammatory conditions [Review]. Int Rev Neurobiol 2007, 79:227-268.

25. Ratajczak J, Wysoczynski M, Hayek F, Janowska-Wieczorek A, Ratajczak MZ: Membrane-derived microvesicles: Important and under-appreciated mediators of cel-to-cell communication. Leukemia 2006, 20: I 487-I495.

26. Kim HK, Song KS, Chung JH, Lee KR, Lee SN: Platelet microparticles induce angiogenesis in vitro. $\mathrm{Br} J$ Haematol 2004, 124:376-384.

27. Brill A, Dashevsky O, Rivo J, Gozal Y, Varon D: Platelet-derived microparticles induce angiogenesis and stimulate postischemic revascularization. Cardiovasc Res 2005, 67:30-38.

28. Welterman A, Hron G, Kollars M: The association between tissue factor-exposing microparticles and the activation of the coagulation system in cancer patients. Blood 2004, 104:709a. (Abstract 2589)

29. Janowska-Wieczorek A, Wysoczynski M, Kijowski J, Marquez-Curtis L, Machalinski B, Ratajczak J, Ratajczak MZ: Microvesicles derived from activated platelets induce metastasis and angiogenesis in lung cancer. Int J Cancer 2005, I / 3:752-760.

30. Clemetson KJ, Clemetson JM, Proudfoot AE, Power CA, Baggiolini M, Wells TN: Functional expression of CCRI, CCR3, CCR4, and CXCR4 chemokine receptors on human platelets. Blood 2000 , 96:4046-4054. 
31. Mause SF, von Hundelshausen P, Zernecke A, Koenen RR, Weber C: Platelet microparticles, a transcellular delivery system for RANTES promoting monocyte recruitment on endothelium. Arterioscl Thromb Vasc Biol 2005, 25:15/2-15/8.

32. MacKenzie A, Wilson HL, Kiss-Toth E, Dower SK, North RA, Surprenant $A$ : Rapid secretion of interleukin-I $\beta$ by microvesicle shedding. Immunity 200I, 8:825-835.

33. Rozmyslowicz T, Majka M, Kijowski J, Murphy SL, Conover DO, Poncz M, Ratajczak J, Gaulton GN, Ratajczak MZ: Platelet- and megakaryocyte-derived microparticles transfer CXCR4 receptor to CXCR4-null cells and make them susceptible to infection by X4-HIV. AIDS 2003, 17:33-42.

34. Jy W, Mao WW, Horstman LL, Tao J, Ahn YS: Platelet microparticles bind, activate and aggregate neutrophils in vitro. Blood Cells Mol Dis 1995, 2 I(3):217-23।.

35. Han MH, Hwang SU, Roy DB, Lundgren DH, Price JV, Ousman SS, Fernald GH, Gerlitz B, Robinson WH, Baranzini SE, Grinnell BW, Raine CS, Sobel RA, Han DK, Steinman L: Proteomic analysis of active multiple sclerosis lesions reveals therapeutic targets. Nature 2008, 45 I: I076-I08I.

36. Granier H, Bellard S, Nicholas X, Laborde JP, Thlarmin F: Association sclerose en plaques et thrombopenie auto-immune. Rev Med Interne 200I, 22:127I-7.

37. Munteis E, Segura N, Martinez JE, Cuadrado E, Galvez A, Roquer J: Idiopathic thrombocytopenic purpura in patients with multiple sclerosis. (Abstract). Multiple Sclerosis 2006, I2:S2I0.

38. Madrid A, Ucles A, Gonzalez-Marcos JR, Gil-Peralta A: Relacion entree sclerosis multiple, enfermedad de Hodgkin y purpura trombocitopenica idiopatica. Relations among multiple sclerosis, Hodgkin's disease and idiopathic thrombocytopenic purpura. Neurologia 1997, 1 2:96-97.

39. Segal JB, Powe NR: Prevalence of immune thrombocytopenia: analyses of administrative data. J Thromb Haemost 2006 4(II):2377-2883.

40. Kirby S, Brown MG, Murray TJ, Fisk JD, Stadnyk K, MacKinnon-Cameron D, Bhan V: Prevalence of other autoimmune diseases in patients with multiple sclerosis. Multiple Sclerosis 2005, I I(Suppl I):S29.

4I. Tans G, Rosing J, Thomassen MC, Heeb MJ, Zwaal RF, Griffin JH: Comparison of anticoagulant and procoagulant activities of stimulated platelets and platelet-derived microparticles. Blood 199I, 77:2641-2648.

42. Sugiyama $Y$, Yamamoto $Y$ : Characterization of serum anti-phospholipid antibodies in patients with multiple sclerosis. Tohoku J Exp Med 1996, 178(3):203-2I5.

43. Bidot CJ, Horstman LL, Jy W, Jimenez JJ, Bidot C Jr, Ahn YS, Alexander JS, Minagar A: Clinical and neuroimaging correlates of antiphospholipid antibodies in multiple sclerosis: a preliminary study. BMC Neurol 2007, 7:36.

44. Cuadrado M], Khamashta MA, Ballesteros A, Godfrey T, Simon MJ, Hughes GR: Can neurological manifestations of Hughes (antiphospholipid) syndrome be distinguished from multiple sclerosis? Analysis of 27 patients and review of the literature. Medicine (Baltimore) 2000, 79:57-68.

45. Sheremata $W$, Minagar A, Alexander J, Vollmer T: The role of alpha-4 Integrin in the aetiology of multiple sclerosis: current knowledge and therapeutic implications. CNS Drugs 2005, 19:909-922.
Publish with Biomed Central and every scientist can read your work free of charge

"BioMed Central will be the most significant development for disseminating the results of biomedical research in our lifetime. "

Sir Paul Nurse, Cancer Research UK

Your research papers will be:

- available free of charge to the entire biomedical community

- peer reviewed and published immediately upon acceptance

- cited in PubMed and archived on PubMed Central

- yours - you keep the copyright
BioMedcentral 